\title{
A prospective case-control and molecular epidemiological study of human cases of Shiga toxin-producing Escherichia coli in New Zealand
}

Patricia Jaros ${ }^{1 *}$, Adrian L Cookson², Donald M Campbell ${ }^{3}$, Thomas E Besser ${ }^{4}$, Smriti Shringi $^{4}$, Graham F Mackereth $^{5}$, Esther Lim ${ }^{5}$, Liza Lopez ${ }^{6}$, Muriel Dufour ${ }^{5}$, Jonathan C Marshall', Michael G Baker ${ }^{7}$, Steve Hathaway ${ }^{3}$,

Deborah J Prattley ${ }^{1}$ and Nigel P French ${ }^{1,8}$

\begin{abstract}
Background: Shiga toxin-producing Escherichia coli (STEC) O157:H7 and related non-O157 STEC strains are enteric pathogens of public health concern worldwide, causing life-threatening diseases. Cattle are considered the principal hosts and have been shown to be a source of infection for both foodborne and environmental outbreaks in humans. The aims of this study were to investigate risk factors associated with sporadic STEC infections in humans in New Zealand and to provide epidemiological information about the source and exposure pathways.
\end{abstract}

Methods: During a national prospective case-control study from July 2011 to July 2012, any confirmed case of STEC infection notified to regional public health units, together with a random selection of controls intended to be representative of the national demography, were interviewed for risk factor evaluation. Isolates from each case were genotyped using pulsed-field gel electrophoresis (PFGE) and Shiga toxin-encoding bacteriophage insertion (SBI) typing.

Results: Questionnaire data from 113 eligible cases and 506 controls were analysed using multivariate logistic regression. Statistically significant animal and environmental risk factors for human STEC infections were identified, notably 'Cattle livestock present in meshblock' (the smallest geographical unit) (odds ratio 1.89, 95\% Cl 1.04-3.42), 'Contact with animal manure' (OR 2.09, 95\% Cl 1.12-3.90), and 'Contact with recreational waters' (OR 2.95, 95\% Cl 1.30-6.70). No food-associated risk factors were identified as sources of STEC infection. E. coli O157:H7 caused 100/113 (88.5\%) of clinical STEC infections in this study, and 97/100 isolates were available for molecular analysis. PFGE profiles of isolates revealed three distinctive clusters of genotypes, and these were strongly correlated with SBI type. The variable 'Island of residence' (North or South Island of New Zealand) was significantly associated with PFGE genotype $(p=0.012)$.

Conclusions: Our findings implicate environmental and animal contact, but not food, as significant exposure pathways for sporadic STEC infections in humans in New Zealand. Risk factors associated with beef and dairy cattle suggest that ruminants are the most important sources of STEC infection. Notably, outbreaks of STEC infections are rare in New Zealand and this further suggests that food is not a significant exposure pathway.

Keywords: Prospective case-control study, Sporadic STEC infections, New Zealand, Risk factors, Source attribution, Cattle, Molecular epidemiology, Pathways of infection, Population attributable fractions

\footnotetext{
* Correspondence: P.Jaros@massey.ac.nz

'Molecular Epidemiology and Public Health Laboratory, Hopkirk Research Institute, Massey University, Private Bag, 11 222, Palmerston North 4442, New Zealand

Full list of author information is available at the end of the article
}

\section{Biomed Central}

(C) 2013 Jaros et al.; licensee BioMed Central Ltd. This is an Open Access article distributed under the terms of the Creative Commons Attribution License (http://creativecommons.org/licenses/by/2.0), which permits unrestricted use, distribution, and reproduction in any medium, provided the original work is properly cited. 


\section{Background}

Shiga toxin-producing Escherichia coli (STEC) O157:H7 and related non-O157 STEC strains are pathogens of public health concern worldwide. They can cause severe outbreaks of gastrointestinal illness with clinical symptoms ranging from diarrhoea and haemorrhagic colitis to the life-threatening haemolytic uraemic syndrome [1]. Ruminants, particularly cattle, are considered to be an important reservoir of STEC, shedding the pathogen via faeces [2-4], and are a primary source of foodborne and environmental outbreaks of STEC in humans $[5,6]$.

Food products of animal and plant origin have been confirmed as vehicles of disease transmission in casecontrol studies of STEC outbreaks and sporadic STEC infections; these included raw milk [7-9], unpasteurised cheese [10], undercooked hamburgers [11-13], sausages $[14,15]$, leafy lettuce [16] and unpasteurised apple cider [17]. Implicated food vehicles were most commonly contaminated directly or indirectly with ruminant faeces containing STEC before or after processing. Similarly, faecally contaminated recreational waters and water supplies have been identified as environmental sources of human STEC infections [18-20]. Exposures to farming environments have been reported as risk factors of sporadic STEC infections, particularly for young children [8,21].

Improvements in surveillance of STEC infections, following their recognition as serious public health concerns, have resulted in an overall increasing trend of STEC notifications at the international level. Over the past decade, non-O157 STEC cases have been reported more frequently in the USA and the EU [22,23], a feature that might be attributed to improved laboratory methods for isolation of non-O157 STEC serotypes and additional laboratory testing of specimens for non-O157 STECs.

Since 1993, when New Zealand's first case of STEC infection in humans was reported [24], the annual number of notified STEC cases has increased steadily. In 2012, 147 cases of STEC (3.3 cases per 100,000 population) were recorded in the national surveillance database (EpiSurv) used by regional public health units (PHU) to record epidemiological data from notified cases of communicable and other diseases [25]. All but five cases were confirmed by culture isolation and identified as STEC serotypes O157:H7 (83.8\%) and non-O157 (16.2\%). Although the majority of reported STEC cases in New Zealand are caused by serotype O157:H7, the percentage of non-O157 STEC cases has increased steadily over the past five years from $1.6 \%$ in 2008 to $16.2 \%$ in 2012.

While STEC infections in New Zealand appear as sporadic cases or small clusters, little is known about the relative importance of cattle as a reservoir, or the relative contribution of different exposure pathways to human cases of STEC.
The primary objective of this study was the identification of risk factors associated with sporadic STEC infections acquired in New Zealand so as to gain epidemiological knowledge on the source and exposure pathways for this disease. A second objective was to conduct a molecular epidemiological investigation of STEC isolates from clinical cases.

\section{Methods}

\section{Study design, definition of cases and controls}

A national prospective case-control study was conducted in New Zealand from $18^{\text {th }}$ July 2011 to $31^{\text {st }}$ July 2012 . A case was defined as a patient with (i) clinical symptoms of diarrhoea and/or haemolytic uraemic syndrome and/or thrombotic thrombocytopaenia purpura, (ii) an onset of clinical disease at a maximum of two weeks prior to being reported to a PHU, (iii) an infection most likely acquired in New Zealand, (iv) confirmed by isolation of STEC from a clinical specimen, and (v) the primary STEC infection in a household. Study cases were interviewed by phone or in person by trained PHU staff using a questionnaire on multiple risk factors potentially associated with STEC infections.

Study controls, intended to be representative of the national demography, were selected randomly from the New Zealand population. An eligible control had to be free of symptoms of diarrhoea or any other gastrointestinal disease at the time of interview, and in the two weeks prior to the interview. Monthly quotas of controls were recruited by a professional survey provider (UMR Research, Wellington, New Zealand) using random landline dialling from the New Zealand phone directory. Controls were contacted in the third week of every month. In each household, the individual with the last birthday was chosen as the study participant. A computer-assisted telephone interview was conducted by a trained team of assigned interviewers using the same questionnaire as that used for cases.

Informed consent was obtained from all study participants before being interviewed. For study cases and controls aged $<18$ years, a parent or adult caregiver served as the interview respondent after their consent was acquired.

\section{Questionnaire}

A standardised questionnaire (Additional file 1) was used to collect data from study cases and controls concerning potential risk factors for infection in the two weeks before onset of disease (cases) and the telephone interview (controls). The questionnaire covered demographic characteristics and exposure categories such as food consumed (treated/raw milk and products thereof, various raw/pink meats, fish, raw fruit and vegetables, and purchased fruit juices), dining locations, supply of drinking water (town supply, private bore, roof run-off, creek, tanker truck), 
contact with recreational waters, hunting activities, contacts with animals and humans, recent travels, and medications taken (antibiotic and antacid). To investigate the spatial distribution of study participants, while protecting privacy, cases and controls were asked to name the nearest school to their home to assign their geographical locality. The month and year of interview was recorded to investigate the seasonality of disease. The questionnaire was cognitive and pilot tested.

\section{Sample sizes of cases and controls}

Epi Info $^{\text {тm }}$ software [26] was used to calculate the sample size for cases and to perform power calculations for three different expected frequencies of exposure among controls. Based on a predicted sample size of 150-170 cases (expected number of cases based on STEC cases notified nationally in two preceding years) and an attempted case to control ratio of 1:3, there was sufficient statistical power (at least $80 \%$ ) at a confidence level of $95 \%$ to detect an odds ratio of 3.0 , using $5 \%, 20 \%$ and $80 \%$ as the expected frequencies of exposure among controls. Hence, the sample size of controls was set at 506 and included oversampling of children $0-4$ years of age $(n=200)$ to provide a similar predicted ratio of cases and controls (1:3) as this age group showed the highest number of reported STEC cases in the past. A monthly quota of 42 controls was interviewed by the survey provider.

\section{STEC isolates of study cases}

Clinical cases were confirmed by culture isolation of STEC from clinical specimens submitted to medical laboratories or the Enteric Reference Laboratory (ERL, Institute of Environmental Science \& Research Ltd, Upper Hutt, New Zealand). STEC isolates were submitted to ERL for serotyping, testing for the presence of virulence genes $(e h x \mathrm{~A}$, $e a e, s t x 1, s t x 2)$, and genotyping using pulsed-field gel electrophoresis (PFGE, restriction enzyme $\mathrm{XbaI}$ ). Isolates were sent to the Molecular Epidemiology and Public Health Laboratory ( ${ }^{m}$ EpiLab, Hopkirk Research Institute, Massey University, Palmerston North, New Zealand) for screening for the presence of virulence gene subtype stx2c. In addition, E. coli O157:H7 isolates were genotyped using Shiga toxin (Stx)-encoding bacteriophage insertion (SBI) typing (Prof. Thomas E. Besser and colleagues at Washington State University, Pullman, USA) [27,28].

\section{Ethical approval}

This study was approved by the Multi-region Ethics Committee, Wellington, New Zealand, on 17 June 2011; reference number MEC/11/04/043.

\section{Data management and statistical analysis}

$\mathrm{R}$ software (version 2.15.2) [29] was used for all statistical analysis, with significance set at $p<0.05$.
Datasets of cases and controls were screened for completeness prior to analysis. Descriptive statistics were calculated for each study group. To account for potential confounding from imperfect frequency matching on age, the variable 'Age' was categorised by grouping 'pre-school children' (0-4 years), 'children/students' (5-19 years), and 'adults' (>19 years).

To illustrate the spatial distribution of study participants, New Zealand Transverse Mercator coordinates (NZTM2000) of named schools were plotted, using R packages 'maptools' [30] and 'spatstat' [31]. Based on the spatial distribution of cases and controls, a relative risk surface of STEC cases for New Zealand was produced, using $\mathrm{R}$ package 'sparr' [32]. To account for spatial heterogeneity, an adaptive estimate was utilised for case and control densities with an average smoothing bandwidth of $50 \mathrm{~km}$. Areas with values $>0.0$ indicate increased relative risks of STEC infection. For comparison, cattle densities were mapped by regions of New Zealand; using the sum of beef and dairy cattle numbers from 2011 [33] divided by the area $\left(\mathrm{km}^{2}\right)$ of each region.

In addition to the data generated by the case-control questionnaires, information on ruminant livestock numbers from a national livestock database [34] was used in two separate analyses. Firstly, additional variables were generated, representing whether particular species of livestock (dairy cattle, beef cattle, sheep, and deer) were farmed in meshblocks (the smallest geographic unit of statistical data collected for Statistics New Zealand) in which the cases and controls resided. These additional variables (presence/absence, numbers and density of each species) were used in the logistic regression analysis of the case-control dataset.

Secondly, in order to extend the analysis of the relationship between ruminant livestock (dairy cattle, beef cattle, sheep, and deer) and the risk of STEC, a separate logistic regression analysis was conducted at the meshblock level. The relationship between ruminant livestock (presence/ absence, numbers and density of each species) and the risk of STEC notification in all meshblocks of New Zealand was assessed. In essence, this analysis used the cases from the case-control study, but extended the control set to consider the entire population of New Zealand.

For both logistic regression analyses, ruminant livestock data from 2009 were used as they represented the most reliable recent data that could be linked to geographical boundaries (meshblocks) and the most recent human census data. The last population census (2006) estimated a national human population of 4,027,527.

\section{Multivariate logistic regression model building}

Questionnaire answers of "unknown" or "not sure" were treated as missing values of the exposure variables. Exposure variables were analysed using univariate and 
multivariate logistic regression to identify risk factors associated with sporadic STEC cases. Exposure variables with Wald test or Likelihood ratio tests $p$-values $<0.20$ in univariate analysis were tested for correlation, and included in an initial multivariate model if their correlation values were $< \pm 0.30$.

To generate a preliminary multivariate model, stepwise backward- and forward-elimination of least significant variables and those with correlation values of $\geq \pm 0.30$, respectively, was used, while eliminated variables were assessed for confounding. The confounding effect was determined by a change of $>30 \%$ in a variable coefficient in the model after another variable was dropped from or added to the model. Variables which demonstrated confounding were retained in the model even if they were non-significant. Biologically plausible interactions between variables were assessed to generate the final multivariate model.

To adjust for a proportion of missing values in relevant variables such as 'Contact with animal manure' (cases: $n=13$, controls: $n=7$ ), 'Contact with children wearing nappies' (cases: $n=6$, controls: $n=4$ ), and 'Contact with person vomiting/having gastrointestinal disease' (cases: $n=10$, controls: $n=16$ ), multiple imputations by chained equations [35] were applied on the final multivariate model using $\mathrm{R}$ package 'mice' [36]. Likelihood ratio tests and the le Cessie-van Houwelingen normal test statistics [37] were applied to evaluate the model's significance and goodness-of-fit, respectively, using $\mathrm{R}$ package 'rms' [38]. Models were compared using the Akaike information criterion (AIC), a measure of the relative goodness of fit.

For the extended analysis of the relationship between ruminant livestock and the risk of STEC at the meshblock level, a second multivariate logistic regression model was built. In this analysis the number of STEC cases out of the population in each meshblock was the outcome variable (a two-column vector of the number of cases out of the population in each meshblock) and variables representing each ruminant species per meshblock were considered as exposure variables (presence/absence, numbers and density).

\section{Population attributable fractions (PAF)}

To assess the proportion of sporadic STEC disease in the study population attributable to a specific exposure, the variable's population attributable fraction $\left(\mathrm{PAF}_{\mathrm{i}}\right)$ was computed. PAF of variables associated with increased risk of STEC infection were estimated using the following formula $[39,40]$ :

$$
P A F_{i}=\frac{p_{i}\left(a O R_{i}-1\right)}{a O R_{i}} \times 100 \%,
$$

where $p_{i}$ is the proportion of all study cases within a categorical variable and a reference category denoted by $i=1$, and $a O R_{i}$ is the adjusted variable-specific odds ratio derived from the final multivariate model. Medians and 95\% credible intervals were computed from 1,000 simulations as described in Stafford et al. [39].

\section{Molecular analysis of $E$. coli 0157:H7 isolates}

PFGE profiles of the clinical E. coli O157:H7 isolates were analysed and compared using BioNumerics software (version 6.6) [41] to create a dendrogram applying UPGMA (unweighted pair group method with arithmetic mean) cluster analysis using the Dice similarity coefficient, with a band matching tolerance of $1 \%$.

Fisher's exact test was used to evaluate the association between SBI genotypes and exposure variables considered in the multivariate logistic regression analysis. A distance matrix of isolates' PFGE profiles was generated in BioNumerics and linked with exposure variables, to analyse the molecular relatedness of isolates and estimate the proportional contribution of these variables to the molecular variation. Multidimensional scaling plots and permutational multivariate analysis of variance (PERMANOVA+, version 1.0.4) were used for this analysis using Primer 6 (version 6.1.14) [42].

\section{Results}

\section{Study population, spatial and temporal epidemiology}

A total of 123 STEC cases meeting the case definition were notified to PHUs during the study period. Eight cases refused to participate in the study, thus resulting in a $93.5 \%$ response rate. Two potential cases were excluded, one due to a high probability of having acquired the infection overseas and the other due to severe illness. Therefore, 113 STEC cases were included in this study, of which 75 (66.4\%) were interviewed by phone and 35 (31.0\%) were visited by PHU staff; the interviewing methods of three cases were unknown. The majority of STEC cases $(83.2 \%, 94 / 113)$ were interviewed within 0-5 days of notification (12 cases within 6-9 days, four cases within 10-12 days, and three cases within 21 days). Of these 113 STEC cases, 100 (88.5\%) were E. coli O157:H7 and 13 (11.5\%) were non-O157 STEC.

To recruit 506 controls, including 200 0-4 year-old children, a total of 7864 phone calls were made. Contact was established for $66.8 \%(5254 / 7864)$ of phone calls and of those contacted, $62.2 \%$ (3266/5254) were interested in participating in the study (response rate). From 3266 interested respondents, 84.5\% (2760/3266) were not eligible mainly because of not fitting the required monthly quota of $0-4$ year-olds (93.6\% (2583/2760)), or not meeting the selection criteria.

Males comprised 52.2\% (59/113) of cases and $42.9 \%$ (217/506) of controls. The median age of cases and controls were 7.0 years (interquartile range 2.0-29.0) and 11.5 years (IQR 3.0-58.0), respectively. The age and 
spatial distribution of cases and controls are shown in Figure 1.

The proportional distributions of participants stratified by age categories were: $46.0 \%$ cases (52/113) and $40.3 \%$ controls $(204 / 506)$ for $0-4$ year-old pre-school children; $20.4 \%$ cases $(23 / 113)$ and $12.1 \%$ controls $(61 / 506)$ for 5-19 year-old children/students; and $33.6 \%$ cases (38/113) and $47.6 \%$ controls $(241 / 506)$ for $>19$ year-old adults.

The temporal distribution of cases during the study period showed a peak in summer/autumn (January until April), with no cases reported in July 2011 (Figure 2).

Based on the spatial distribution of cases and controls across New Zealand (Figure 1), increased relative risk estimates of STEC infections were observed in regions such as Northland, Waikato, Taranaki, Canterbury, and Southland, while reduced risks were found in high density urban areas in the Auckland and Wellington regions (Figure 3A). For comparison, areas with high ruminant livestock densities are shown in Figure $3 \mathrm{~B}$ and Additional file 2.

\section{Risk factors}

Bivariate logistic regression results (adjusted for age categories) are provided in the supplementary material (Additional file 3). Statistically significant risk factors and confounding variables ('Eating seafood', 'Dining outside home', 'Water supply to home from private bore/ spring/creek/or stream', 'Contact with children wearing nappies', and 'Taking antacids') of the final multivariate logistic regression model with imputations are presented in Table 1. The equivalent final model without imputation is provided in the supplementary material (Additional file 4).

Animal and environmental exposures were identified as risk factors for sporadic STEC infections including; 'Other household member having contact with animals other than household pets' for pre-school children aged 0-4, 'Cattle livestock present in meshblock', 'Contact with animal manure,' 'Contact with recreational waters', and 'Travelled to areas in New Zealand with interrupted or no main water supply'. Food items such as 'Drinking refrigerated fruit juice from supermarket' and 'Eating raw vegetables' were identified as having a protective effect rather than being risk factors for STEC infections. When the final multivariate logistic regression model was applied to E. coli O157:H7 cases only, the strength of associations and significance of variables remained relatively unchanged (data not shown), except for the variable 'Contact with recreational waters', which became non-significant (adjusted odds ratio 2.13, 95\% CI 0.84$5.42, p=0.112$ ). This could be explained by a higher proportion of non-O157 cases $(30.8 \%, 4 / 13)$ being exposed to this risk factor compared to $\mathrm{O} 157$ cases $(11.0 \%, 11 / 100)$.

For the multivariate analysis considering cases and the whole population at the meshblock level, the univariate logistic model identified significant associations between STEC and dairy cattle, beef cattle, and sheep, where variables with different functional forms were considered including presence/absence, numbers of animals and densities per $\mathrm{km}^{2}$. The best fitting variables, in terms of AIC, were presence/absence of cattle and sheep. These included presence of beef cattle (odds ratio 2.45, 95\% CI $1.65-3.59$, Wald test $p$-value $<0.001, \mathrm{AIC}=1556.9)$, presence of dairy cattle (OR 2.14, 95\% CI 1.27-3.42, $p=$ 0.003 , AIC $=1567.5)$, presence of all cattle (OR 2.40, 95\% CI 1.62-3.52, $p<0.001$, AIC $=1557.6)$, and presence of sheep (OR 1.98, 95\% CI 1.29-2.97, $p=0.001$, AIC $=$ 1565.7). When considered in multivariate models, there was strong confounding and collinearity between these variables but only species combinations of beef cattle with dairy cattle (Likelihood ratio test $p$-value $<0.001$,
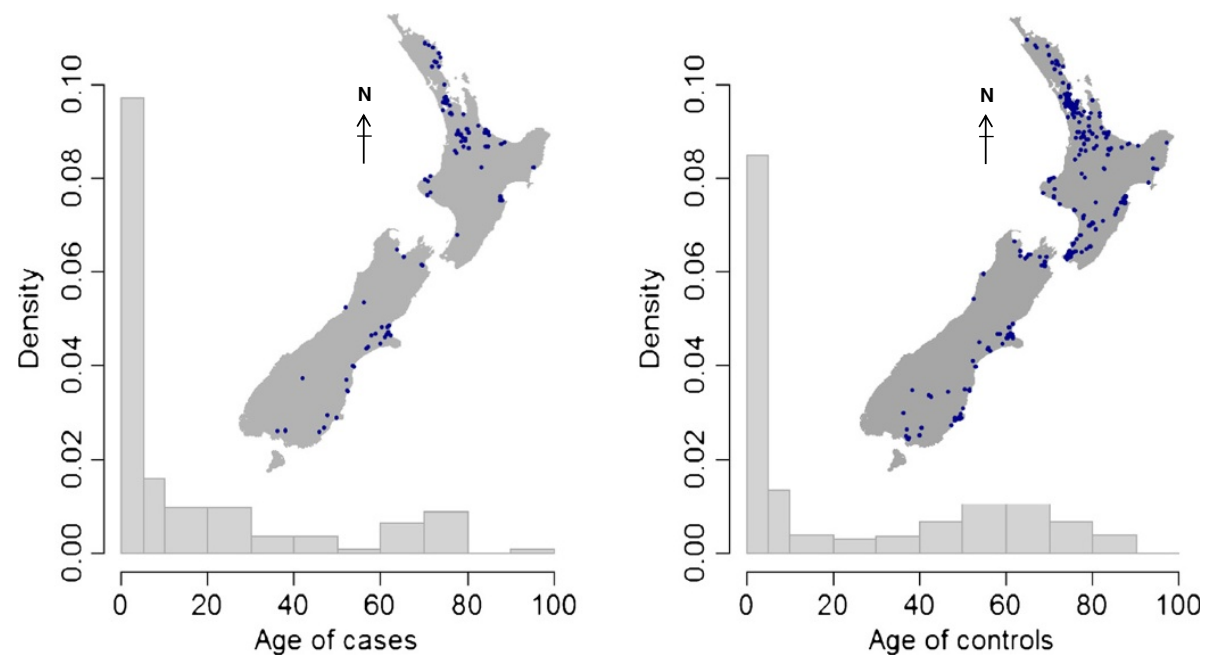

Figure 1 Age and spatial distribution of STEC cases $(n=113)$ and controls $(n=506)$ across New Zealand. 


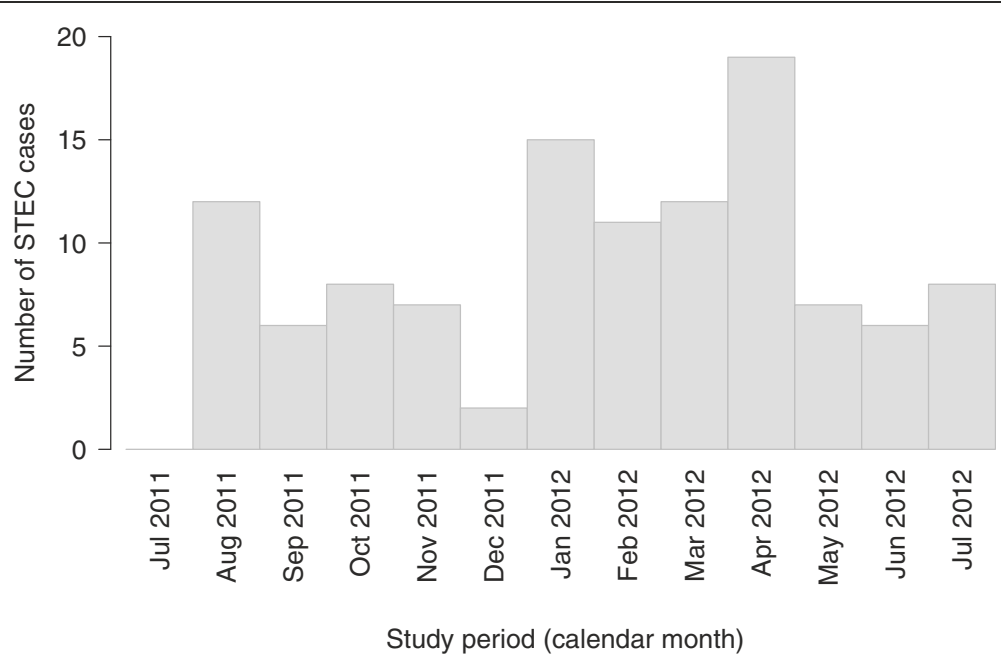

Figure 2 Temporal distribution of sporadic STEC cases $(n=113)$ from July 2011 to July 2012.

$\mathrm{AIC}=1558.9)$, and dairy cattle with sheep $(p=0.005$, $\mathrm{AIC}=1566.6)$ provided biologically meaningful results. According to lowest AIC, the variable presence of beef cattle fitted the best.

\section{Population attributable fractions (PAF)}

PAF of exposure variables associated with increased risk for sporadic STEC infections (Table 1) are summarised in Table 2. The interaction term 'Other household member having contact with animals other than household pets' for 0-4 year-old children, 'Cattle livestock present in meshblock' and 'Contact with animal manure' showed the highest estimated proportions that could be attributed to STEC infections in the study population.

\section{Molecular analysis of $E$. coli $0157: \mathrm{H7}$ isolates}

E. coli O157:H7 and non-O157 STECs, as confirmed by isolation, caused 100/113 (88.5\%) and 13/113 (11.5\%) of the STEC infections, respectively. The non-O157 STECs were of serogroups O26, O84, O103, O123, O176, O180, and ONT (O serogroup not typable). Only 97/100 O157: $\mathrm{H} 7$ isolates and their PFGE profiles were available for molecular analysis; PFGE profiles of non-O157 STEC isolates were not available. The most frequent SBI types

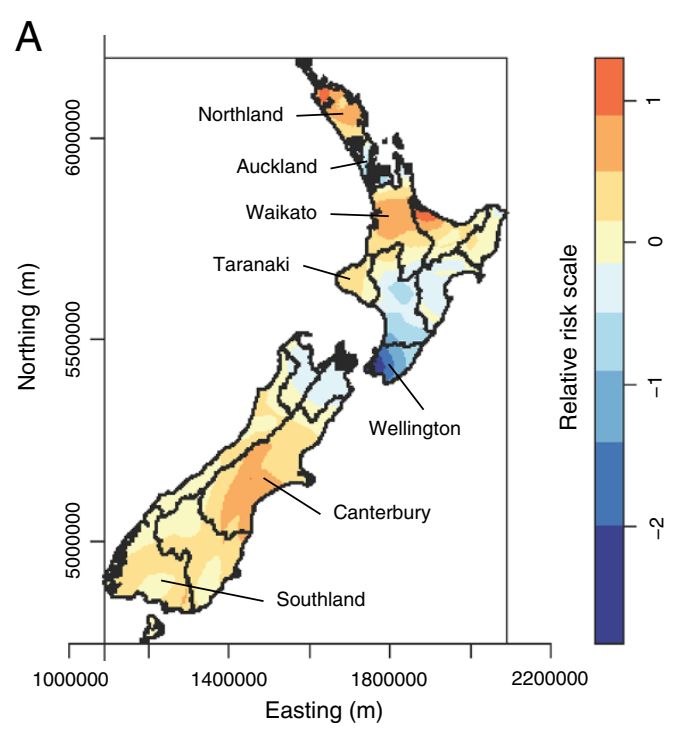

B

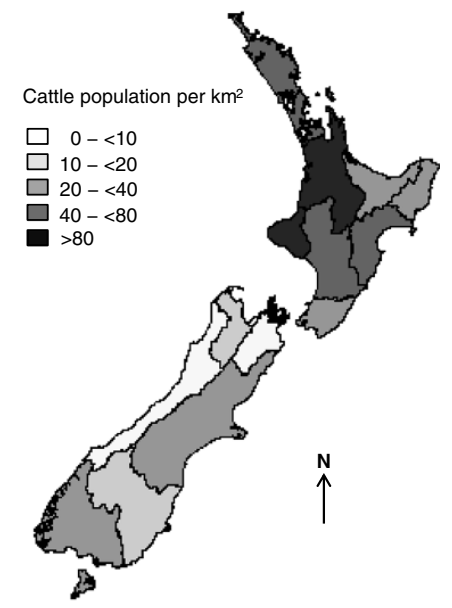

Figure 3 (A) Relative risk estimates of sporadic STEC infection across New Zealand and (B) cattle density from 2011. (A) The bivariate kernel density plot shows estimates of relative risks of STEC infection across regions in New Zealand. Values $>0$ on the relative risk scale indicate increased risk of infection. (B) Total cattle density (dairy and beef animals/ $/ \mathrm{km}^{2}$ ) from 2011 is shown to indicate areas with high cattle densities. Similar plots of the densities of dairy, beef, sheep, and deer are provided in the supplementary material (Additional file 2). 
Table 1 Multivariate logistic regression model showing risk factors for sporadic cases of STEC infections in New Zealand

\begin{tabular}{|c|c|c|c|}
\hline Variable & Coefficient (SE) $^{a}$ & Adjusted odds ratio $(95 \% \mathrm{Cl})^{b}$ & $p$-value ${ }^{c}$ \\
\hline \multicolumn{4}{|l|}{ Other household member having contact with animals other than household pets ${ }^{d_{*}}$} \\
\hline for $0-4$ year-old & $1.39(0.42)$ & $4.03(1.78-9.13)$ & 0.001 \\
\hline for $5-19$ year-old & $-0.77(0.67)$ & $0.47(0.13-1.72)$ & 0.251 \\
\hline for $>19$ year-old & $0.30(0.49)$ & $1.35(0.51-3.56)$ & 0.541 \\
\hline Cattle livestock present in meshblock & $0.64(0.30)$ & $1.89(1.04-3.42)$ & 0.037 \\
\hline Contact with animal manure & $0.74(0.32)$ & $2.09(1.12-3.90)$ & 0.021 \\
\hline Contact with recreational waters & $1.08(0.42)$ & $2.95(1.30-6.70)$ & 0.010 \\
\hline Travelled to areas in New Zealand with interrupted or no main water supply & $0.89(0.43)$ & $2.43(1.04-5.65)$ & 0.040 \\
\hline Handling raw offal & $-0.94(0.35)$ & $0.39(0.20-0.78)$ & 0.008 \\
\hline Drinking refrigerated fruit juice from supermarket & $-1.37(0.32)$ & $0.25(0.14-0.47)$ & $<0.001$ \\
\hline Visiting childcare/kindergarten/or school & $-0.92(0.31)$ & $0.40(0.22-0.73)$ & 0.003 \\
\hline Eating raw vegetables & $-0.65(0.33)$ & $0.52(0.27-0.99)$ & 0.046 \\
\hline Eating seafood & $-0.52(0.27)$ & $0.59(0.35-1.02)$ & 0.057 \\
\hline Dining outside home & $-0.44(0.29)$ & $0.65(0.37-1.14)$ & 0.133 \\
\hline Water supply to home from private bore/spring/creek/or stream & $0.62(0.39)$ & $1.85(0.86-4.00)$ & 0.117 \\
\hline Contact with children wearing nappies & $-0.33(0.31)$ & $0.72(0.39-1.33)$ & 0.298 \\
\hline Taking antacids & $-0.84(0.58)$ & $0.43(0.14-1.34)$ & 0.147 \\
\hline \multicolumn{4}{|c|}{$\begin{array}{l}\text { Likelihood ratio test }=153.70(\mathrm{df}=18, p<0.001) \text {. } \\
\text { a'Standard error. } \\
\text { b } 95 \% \text { confidence interval. } \\
\text { c } p \text {-values were computed based on } 50 \text { imputations. } \\
\text { dThis variable was modelled using a multiplicative interaction term comprising the variables 'Other household member having contact with animals other than } \\
\text { household pets' and 'Age'. } \\
\text { It can be interpreted as follows: a child } 0-4 \text { years of age is at significantly higher risk of being an STEC case, if another household member had contact with } \\
\text { animals other than household pets, compared to a child of the same age without this risk factor. } \\
{ }^{*} p \text {-value }=0.064 \text { for the variable 'Other household member having contact with animals other than household pets' without the interaction term. }\end{array}$} \\
\hline
\end{tabular}

of $E$. coli $\mathrm{O} 157: \mathrm{H} 7$ isolates were 1 (55/97, 56.7\%), 3 (17/97, $17.5 \%)$, and 5 (20/97, 20.6\%); equivalent to SBI genotypes AY2, WY12, and ASY2c/ASWY2c/SY2c, respectively, according to the recently proposed coding system by Shringi et al. [27]. All isolates of SBI type 1 (AY2) carried the stx2a gene, while all SBI type 3 (WY12) had both the stx $2 \mathrm{a}$ and stx1 genes; all SBI type 5 (ASY2c/SY2c) contained only the stx2c gene.

PFGE profiles of the 97 human E. coli O157:H7 isolates were compared (Figure 4). The two small clusters of indistinguishable PFGE profiles (two clusters of seven and eight isolates) were not concurrent in space and time and therefore do not present clusters of infections or small outbreaks.

Four statistically significant relationships were observed between SBI types and exposure variables considered in the multivariate logistic regression analysis of the case-control study. These were SBI type vs. 'Age' with SBI type 5 isolates being overrepresented in $0-4$ yearold children (Fisher's exact test, $p=0.009$ ); SBI type vs. 'Island of residence' with SBI type 5 isolates being associated with the South Island $(p=0.017)$; SBI type vs. 'Season' with SBI type 3 isolates being overrepresented in autumn $(p=0.034)$, and SBI type vs. 'Contact with animal manure' with SBI type 3 isolates being associated with direct exposure to animal manure $(p=0.047)$.

The molecular relatedness between PFGE profiles of $E$. coli $\mathrm{O} 157: \mathrm{H} 7$ isolates considering SBI types, age of cases and island of residence is shown in Figure 5. PFGE profile clusters were strongly associated with SBI types 1,3 , and 5 (Figure 5A). The cluster containing SBI type 5 was more prevalent in pre-school children ( $0-4$ years) (Figure 5B) and in the South Island (Figure 5C), while SBI types 1 and 3 were found more frequently in the North Island (Figure 5C).

PERMANOVA analysis results in Table 3 show the proportional contribution of variables to the molecular variation of PFGE profiles of the E. coli O157:H7 isolates. Other than SBI type, only island of residence explained a significant amount of the variation in PFGE profiles in multivariate models.

\section{Discussion}

This study was designed to identify risk factors associated with domestically-acquired sporadic STEC infections in humans in New Zealand. The results strongly 
Table 2 Population attributable fractions (PAF in \%) with $95 \%$ credible intervals (Crl in \%) of identified risk factors

\begin{tabular}{|c|c|c|c|c|}
\hline Variable & Cases (n) & $\begin{array}{l}\text { Proportion } \\
\text { of cases }(p)\end{array}$ & $\begin{array}{l}\text { Adjusted } \\
\text { odds ratio }^{\mathrm{a}}\end{array}$ & PAF $(95 \% \text { Crl) })^{b}$ \\
\hline \multicolumn{5}{|c|}{$\begin{array}{l}\text { For children 0-4 years old: Other household member having contact with animals } \\
\text { other than household pets }\end{array}$} \\
\hline No & 28 & 0.549 & Ref & \\
\hline Yes & 23 & 0.451 & 4.03 & $16.82(9.0-23.7)$ \\
\hline \multicolumn{5}{|c|}{ Cattle livestock present in meshblock } \\
\hline No & 74 & 0.655 & Ref & \\
\hline Yes & 39 & 0.345 & 1.89 & $18.20(0.6-29.4)$ \\
\hline \multicolumn{5}{|c|}{ Contact with animal manure } \\
\hline No & 66 & 0.660 & Ref & \\
\hline Yes & 34 & 0.340 & 2.09 & $17.47(4.4-27.7)$ \\
\hline \multicolumn{5}{|c|}{ Contact with recreational waters } \\
\hline No & 97 & 0.866 & Ref & \\
\hline Yes & 15 & 0.134 & 2.95 & $9.41(2.7-16.5)$ \\
\hline \multicolumn{5}{|c|}{ Travelled to areas in NZ with interrupted or no main water supply } \\
\hline No & 96 & 0.865 & Ref & \\
\hline Yes & 15 & 0.135 & 2.43 & $8.17(0.7-15.7)$ \\
\hline \multicolumn{5}{|c|}{ Water supply to home from private bore/spring/creek/or stream } \\
\hline No & 89 & 0.802 & Ref & \\
\hline Yes & 22 & 0.198 & 1.85 & $9.46(-2.5-18.8)$ \\
\hline
\end{tabular}

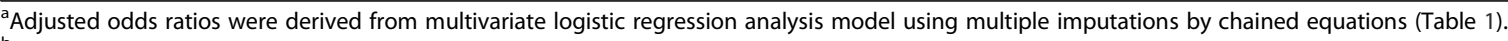

${ }^{\mathrm{b} P A F}$ and $95 \% \mathrm{Crl}$ were computed based on 1000 simulations.

Ref $=$ reference level for comparison.

suggest that direct exposure to animal and/or environmental sources of infection, most likely originating from dairy and beef livestock, is the most important contributor to the burden of sporadic STEC cases observed in New Zealand. No food items were identified as risk factors for sporadic STEC cases in this study.

\section{New Zealand-an agricultural country}

To interpret our findings in context, it is essential to recognise that agriculture is New Zealand's largest primary industry sector contributing to approximately $48 \%$ of New Zealand's export earnings in 2009 [43]. In 2011, 6.1 million dairy cattle, 3.8 million beef cattle, 31.1 million sheep, and 1.0 million deer were recorded in New Zealand. By contrast the estimated human population was approximately 4.4 million with $14 \%$ living in rural areas and only about $1.2 \%$ working in the agricultural industry [33]. Pastoral agriculture is the predominant land use in New Zealand with dairy cattle farming in the flatter and/or wetter areas in Northland, Waikato, Taranaki, and Manawatu in the North Island; and Canterbury, West Coast, Otago, and Southland in the South Island; while sheep and beef cattle farming are practiced in hill and high country areas across both islands.

\section{Spatial and temporal epidemiology}

The highest number of reported STEC infections in this study was in the youngest age category (children aged 0-4 years), which is consistent with New Zealand's health surveillance reports [44-46], and the number of cases peaked in summer/autumn (January until April) [47].

The seasonality of cases is likely to be associated with environmental exposure during the warmer season, such as increased outdoor activities in recreational waters potentially contaminated with STEC from ruminant livestock, but could also be related to the seasonal variation in the prevalence of faecal shedding of STEC in cattle. These phenomena were observed in The Netherlands [48], Great Britain [49], and also in New Zealand during a recent two-year cross-sectional study conducted at four slaughter plants across the country [50]. Similarly, a recent multinational systematic review of seasonality in human zoonotic enteric diseases [51] confirmed a strong summer peak for STEC incidence.

The spatial distribution of sporadic STEC cases across New Zealand has suggested that infections might be associated with farming $[45,46,52]$. We observed increased relative risks of STEC infections in dairy farming regions (Northland, Waikato, Taranaki, Canterbury, and Southland), however, it was not possible to consider dairy and beef farming separately in the analysis of the 


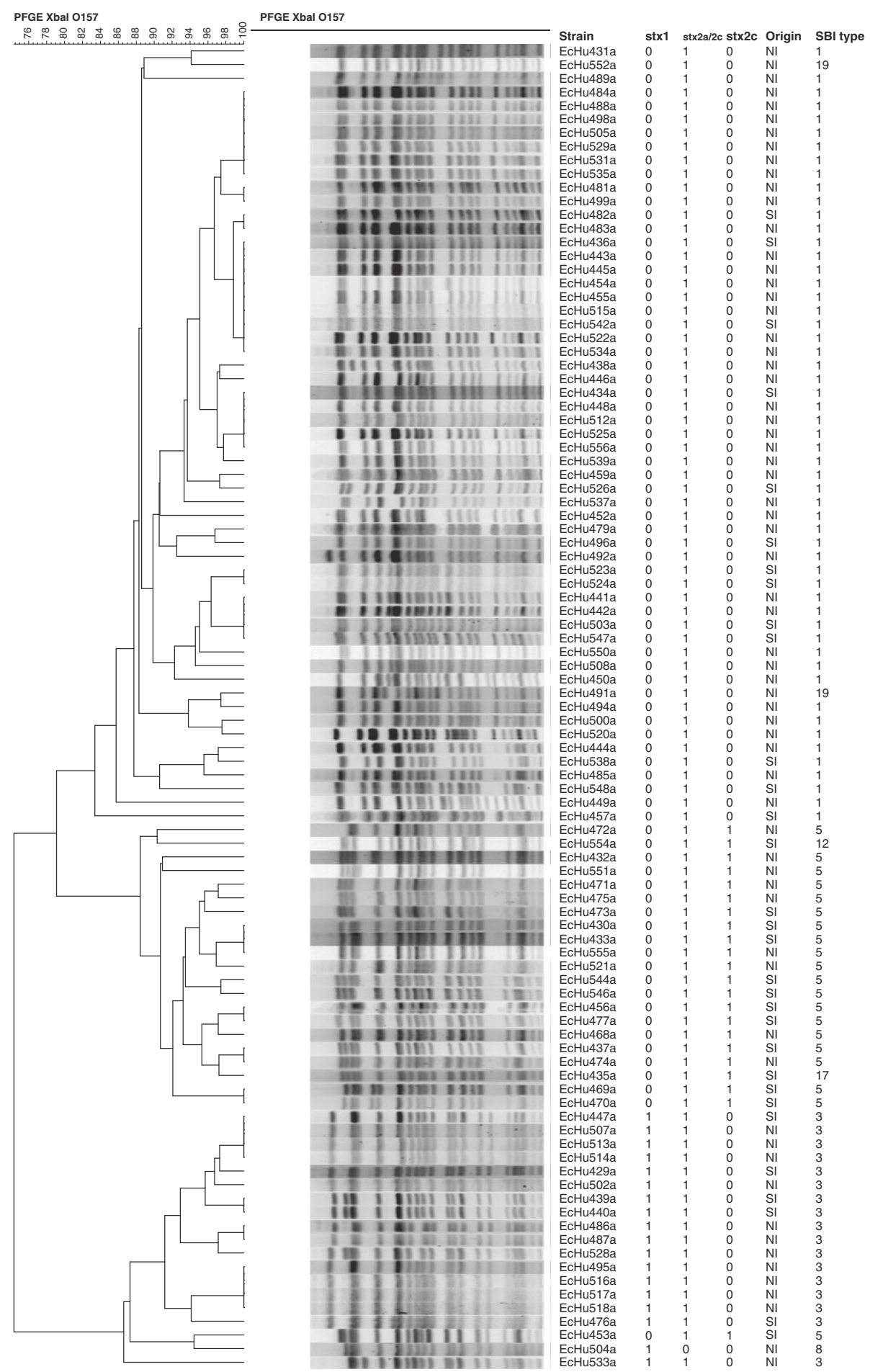

Figure 4 Comparison of PFGE profiles from 97 human E. coli O157:H7 isolates. PFGE profile comparison performed using UPGMA cluster analysis, Dice similarity coefficient, and $1 \%$ band matching tolerance. st $\times 1, s t \times 2 a / c$, st $\times 2 c$ virulence genes encoding for Shiga toxins present (1) or absent (0). Island of residence (Origin) presented as North Island (NI) or South Island (SI) of New Zealand, and genotypes of isolates as Shiga toxin (Stx)-encoding bacteriophage insertion (SBI) types. 


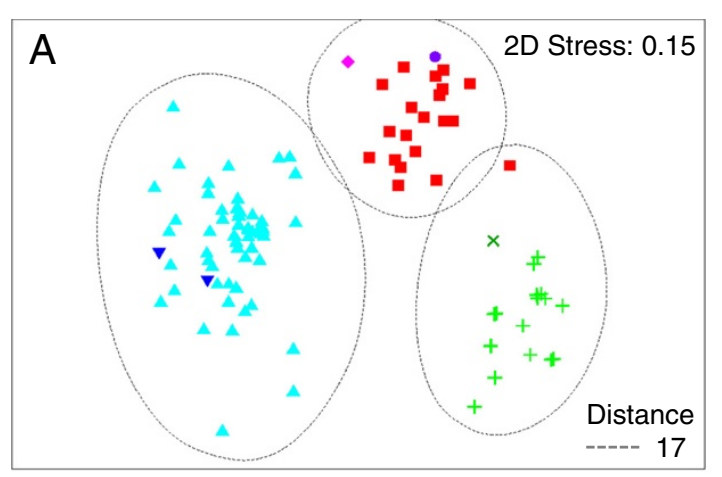

\section{SBI type

1
$\nabla 19$
$\square$
12
-17
$+\quad 3$
$\times \quad 8$

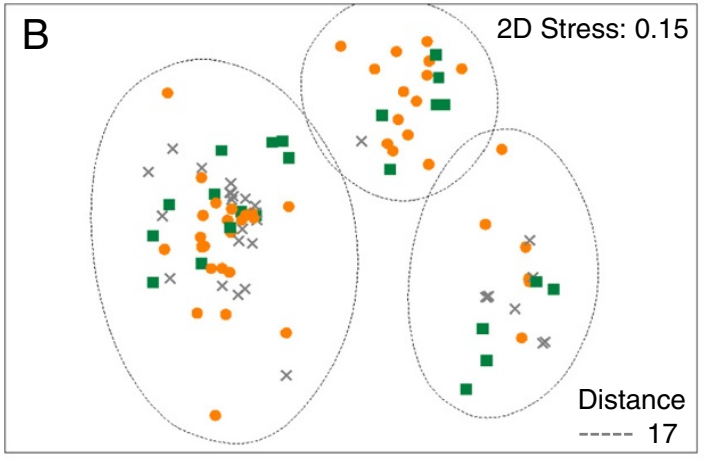

\section{Age}

- 0-4 years

- 5-19 years

$x>19$ years

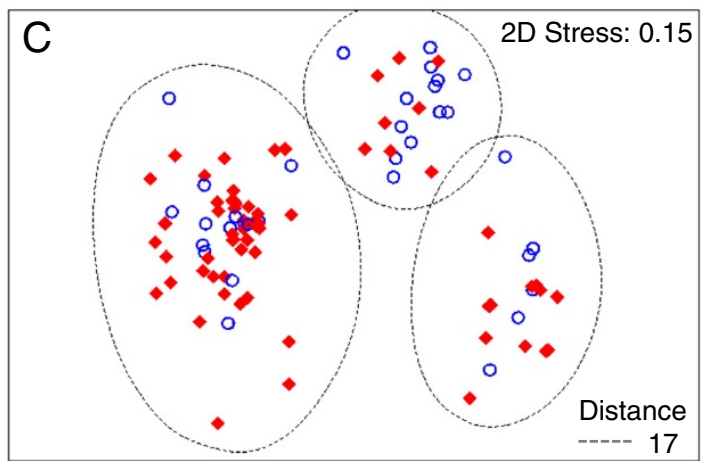

\section{Island of residence \\ - North Island \\ O South Island}

Figure 5 Multidimensional scaling plots (MDS). MDS showing the genotypic clustering of E. coli O157:H7 human isolates and (A) Shiga toxinencoding bacteriophage insertion (SBI) types; (B) age categories; and (C) island of residence. The three clusters of isolates share a genetic difference of $17 \%$ (Distance $=17$ ) based on the isolates' PFGE profiles.

case-control data due to the strong collinearity between these two variables. As all dairy farms in the meshblocks occupied by cases and controls also had beef cattle, hence the two variables were combined into a single variable comprising all cattle. The best fitting variable in the second analysis, which considered the entire

Table 3 PERMANOVA analysis of E. coli 0157:H7 isolates

\begin{tabular}{lrrrrr}
\hline Variable & Df $^{\mathbf{a}}$ & $\begin{array}{r}\text { Mean } \\
\text { square }\end{array}$ & $\boldsymbol{p}^{\text {-value }}$ & Perms $^{\mathbf{b}}$ & $\begin{array}{r}\text { Estimated } \\
\text { component of } \\
\text { variation (\%) }\end{array}$ \\
\hline Island of residence & 1 & 859.0 & 0.012 & 999 & 22.3 \\
Residuals & 95 & 187.5 & & & 77.7 \\
\hline
\end{tabular}

${ }^{a}$ Degrees of freedom.

${ }^{b}$ Number of permutations. population at the meshblock level, was the presence of beef cattle in the meshblock. Associations between STEC infections and areas with higher densities of cattle have been observed in previous studies conducted in The Netherlands [48], Finland [53], Scotland [54], Sweden [55], and Canada [56,57], providing evidence of direct or indirect contact with cattle as a likely source of infection.

\section{Risk factors}

Since reporting of STEC commenced in New Zealand in 1997, cases have occurred sporadically or as small clusters throughout the country, suggesting highly dispersed animal and/or environmental exposures rather than STEC-contaminated food as likely sources of infection. 
In this study, animal and environmental contacts were identified as significant risk factors for sporadic STEC infections. A child $0-4$ years of age was at significantly higher risk, if another household member had contact with animals other than household pets, compared to a child of the same age without this risk factor. This finding is biologically plausible and is more likely to occur in rural than urban settings; for example, when household members working on a farm could be a source of infection. Pre-school children might be exposed to contaminated work clothing and footwear harbouring pathogenic organisms. For example, Campylobacter was recovered from loose debris shaken off protective overalls worn on broiler farms [58]. Household occupation contact with farm animals (sheep or lambs) was also the major risk factor for Salmonella Brandenburg infection in a previous New Zealand case-control study where the infection also particularly affected rural children [59].

In addition, infants and pre-school children exhibit high frequencies of hand-to-mouth and object-to-mouth behaviour indoors and outdoors and this will inevitably increase the risk of ingesting pathogens from clothing, surfaces, objects, hands, and soil $[60,61]$. This is particularly apparent when children are raised in a farming environment, where they are more likely to be exposed to zoonotic and soil-associated pathogens than in urban areas. Therefore, practicing good hand-hygiene and supervising activities of infants and toddlers could help to reduce the risk of ingesting pathogens.

Although 'Living in a rural area' was not statistically significant in our model, there was sufficient evidence that risk factors related to agricultural or rural characteristics were associated with sporadic STEC infection, and these would have confounded the strong univariate relationship with rurality. Similar associations between rurality and notification rates of both STEC and cryptosporidiosis in New Zealand have been observed by Thorburn [62], reporting higher rates in rural areas.

Exposures to farming environments were reported as risk factors for sporadic STEC infections in case-control studies conducted in England [63], North America [11], Germany [8], and Argentina [21]. A prospective casecontrol study by Locking et al. [64] identified contact, or likely contact, with animal manure as a strong risk factor for sporadic STEC O157 infection in Scotland, while a retrospective case-control study by Voetsch et al. [65] observed direct or indirect contact with cattle manure as a leading source of sporadic STEC O157 infections in North America. We also identified contact with animal manure as a significant risk factor in addition to cattle being present in the meshblock in which the case resided. Both variables were associated with the largest population attributable fractions and, when combined with the spatial analysis and the strong correlation between the presence of cattle, and particularly beef cattle and STEC cases at the meshblock level, it indicates that contact with cattle faeces is the major exposure pathway for infection in New Zealand.

'Travelling to areas of New Zealand with interrupted or no main water supply' and 'Contact with recreational waters' emerged as significant environmental risk factors for sporadic STEC infections; activities which increasingly occur in the summer period. Previous studies conducted in Finland [66] and North America [20,67] reported an association between gastrointestinal illnesses, including STEC, after exposure to recreational waters during summer. Such an association could also explain some of the observed seasonality of STEC cases as discussed above. In addition, an estimated $14 \%$ of New Zealand's population is not served by community drinking-water supplies [68] but retrieves drinking water from private springs and bores, streams and creeks, or roof runoffs. This risk applies particularly to residents of rural areas. Considering the large ruminant livestock population in New Zealand, ground water and particularly surface water in rural areas are potentially contaminated with ruminant faeces containing STEC.

We found no evidence to suggest that sporadic STEC cases in New Zealand were associated with exposure to STEC-contaminated food products, while 'Drinking refrigerated fruit juice from supermarket,' 'Eating raw vegetables' and 'Eating seafood' were negatively correlated with disease. An inverse effect of fruit and vegetables has also been reported in previous case-control studies conducted in Australia [69] and Scotland [64] and merits further investigation. The association seems biologically plausible compared to other food products, as they are associated with health benefits such as antimicrobial properties against human pathogens in berries [70] and sweet potato leaves [71]. An alternative explanation might be the association between fruit and vegetable consumption and the participants' choice of healthy eating. This apparent protective effect might also be caused by recall bias, as discussed under sources of bias.

\section{Molecular epidemiology of $E$. coli 0157:H7}

The molecular analysis of PFGE profiles from human $E$. coli $\mathrm{O} 157: \mathrm{H} 7$ isolates revealed three distinctive clusters of genotypes, each represented by a specific SBI type. SBI types are defined based on the insertion site of the Stx-associated bacteriophage and the presence or absence of $s t x$ genes in the bacterial genome, which encode for the Shiga toxin proteins. stx $2 \mathrm{c}$ is a subtype of the $s t \times 2$ gene and characteristic for isolates of SBI type 5 . The observed clustering was significantly associated with 'Island of residence', indicating that SBI type 5 was more prevalent in the South Island, whereas SBI types 1 and 3 were more common in the North Island. This distinct geographical difference in genotype distribution was also 
observed in a recent molecular study including 28 bovine and 209 human E. coli O157:H7 isolates originating from both islands of New Zealand [72]. The distinct between-island distributions of genotypes found among bovine and human isolates indicate localised transmission between cattle and humans. SBI type 5 accounted for $20.6 \%$ of human isolates in that study, which is much greater than its frequency in other international studies [27,73]. This is consistent with a limited historical introduction of this strain into New Zealand and subsequent evolution.

A significant relationship between SBI types and age categories of cases was observed, in particular between SBI type 5 and 0-4 year-old children. It can be hypothesised, if this genotype possesses host-adapted characteristics to affect specifically the immature gastrointestinal tract of children, or whether the observed association is due to SBI type 5 being a more persistent environmental contaminant to which very young children are more likely to be exposed than adults. Recent studies investigating differential virulence of STEC O157 strains have suggested that STEC O157 strains carrying stx2c alone are likely to be less pathogenic compared to strains carrying combinations of stx $2 \mathrm{c}$ and st $x 1$ as shown in a piglet model [74], or less potent on human kidney cell lines and in mouse models [75].

The molecular variation of PFGE profiles of the isolates was explained by only one explanatory variable: 'Island of residence,' which was consistent with the observed clustering of isolates. Together with significant associations observed between SBI types and both 'Season' and 'Contact with animal manure', these findings provide further evidence of an animal/environmental-associated pathway of sporadic STEC infection in New Zealand.

\section{Sources of bias}

The two week window of exposure might have resulted in some recall bias due to difficulty remembering previous exposures. However, this time period was chosen to cover the likely incubation period for STEC (3-12 days) while lists of possible answers facilitated recall of consumed food items, contact with animal species and environmental exposures. Observational studies of this type can also introduce recall bias due to the cases being more likely to recall events than the non-affected controls [76]. This effect could explain the apparent protective association seen for consumption of a range of foods, where recall was less complete amongst controls, as found in a previous New Zealand case-control study of similar populations [59]. In addition, $31 \%$ of cases were interviewed differently to the other cases and controls, which might have introduced some systematic differences between them, though such a bias is unlikely to have had an important effect on the findings.
There was evidence of some selection bias in the control population as a result of using random landline dialling for recruitment. Based on the national census data, the older age group of controls was overrepresented compared to the younger age groups. This might be because younger age groups favouring mobile technology over landlines, or their tendency to reside in relatively fewer households with a larger number of individuals. Nonetheless, little bias was observed in the distribution of ethnicities, gender, and rural/urban living among controls, compared to national census data.

The exclusion of potentially eligible cases had a negligible effect on the findings. Only one case probably acquired their infection overseas so was excluded. There were no apparent outbreaks or clusters of concurrent cases observed during the study period, indicating that secondary infections occur only relatively infrequently in New Zealand suggesting that this study was effectively one of sporadic cases.

The number of confirmed cases reported through the disease surveillance system is likely to be an underestimation of the true incidence of human STEC infections in New Zealand. Scallan et al. [77] and Tam et al. [78], using different approaches, have estimated under-ascertainment fractions of STEC cases in the USA and the UK. Asymptomatic or mild cases are unlikely to present to medical practitioners and not all stool samples received at diagnostic laboratories are routinely tested for E. coli O157:H7 and non-O157 STECs in New Zealand. In addition, the majority of diagnostic laboratories test stool samples of STEC cases for $E$. coli O157:H7 only, which could explain the current predominance of STEC O157. Therefore risks presented could be underestimated, or different measures of association could apply compared to findings in this study.

\section{Conclusions}

Our findings strongly indicate that environmental and animal contact, but not food, are important exposure pathways for sporadic cases of human STEC infection in New Zealand. There are strong indications that dairy cattle and beef cattle are the most important sources of STEC and contact with manure from these animals represents an important exposure pathway. Notably, outbreaks of STEC infections are rare in New Zealand and this further suggests that food is not a significant exposure pathway.

\section{Additional files}

Additional file 1: Questionnaire. Questions asked in interview of study cases and controls.

Additional file 2: Ruminant livestock densities in New Zealand from 2011. Densities (animals $/ \mathrm{km}^{2}$ ) of (A) dairy cattle, (B) beef cattle, (C) sheep, and (D) deer in New Zealand from 2011. 


\section{Additional file 3: Results of bivariate logistic regression analysis (adjusted for age categories).}

Additional file 4: Multivariate logistic regression model without imputations. Results showing identified risk factors after deleting 57 of 619 observations (113 cases and 506 controls) due to missing values. 'No exposure/contact' was chosen as reference level for comparison in each variable (odds ratio $=1.00$ ).

\section{Competing interests}

The authors declare that they have no competing interests.

\section{Authors' contributions}

PJ designed and coordinated the study, performed the screening for st $2 \mathrm{C}$ of isolates, performed the statistical analysis and drafted the manuscript; ALC helped with the study design and reviewed the manuscript; DMC conceived of the study, participated in its design, and reviewed the manuscript; TEB and SS performed the SBI genotyping of isolates; GFM helped with study design, coordination of the study, and reviewed the manuscript; EL set up the Survey Gizmo and database, and LL participated in coordination of study and data collection; MD performed the PFGE genotyping of isolates; JCM contributed to the statistical analysis; MGB contributed to the study design and reviewing of the manuscript; SH and DJP contributed to the study design; NPF contributed to the study design, statistical analysis, drafting and reviewing of the manuscript. All authors read and approved the final manuscript.

\section{Acknowledgements}

We would like to acknowledge Public Health Units across New Zealand for their collaboration and participation in this study; the Health Intelligence team at ESR (Ali Borman, Ruth Pirie, Kerry Sexton) with study preparations and technical support; UMR for recruiting and interviewing study controls; ERL for providing STEC isolates and PFGE profiles (Brent Gilpin, ESR, Christchurch, New Zealand); Charlotte Bolwell (Hopkirk Research Institute, Massey University, Palmerston North, New Zealand) for providing the meshblock data and livestock numbers; Dr John Holmes (Ministry of Health, Wellington, New Zealand) for advice in study design; Martyn Kirk (National Centre for Epidemiology and Population Health, Australian National University, Canberra, Australia) for advice in questionnaire and study design; and the Ministry for Primary Industries (Wellington, New Zealand) for funding this study.

\section{Author details}

${ }^{1}$ Molecular Epidemiology and Public Health Laboratory, Hopkirk Research Institute, Massey University, Private Bag, 11 222, Palmerston North 4442, New Zealand. ${ }^{2}$ Animal Nutrition \& Health Group, AgResearch Ltd, Grasslands Research Centre, Private Bag, 11 008, Palmerston North 4442, New Zealand. ${ }^{3}$ Ministry for Primary Industries, PO Box 2526, Wellington 6140, New Zealand. ${ }^{4}$ College of Veterinary Medicine, Veterinary Microbiology and Pathology, Washington State University, Pullman, WA, USA. ${ }^{5}$ Institute of Environmental Science \& Research Ltd, PO Box 40 158, Upper Hutt 5140, New Zealand. ${ }^{6}$ Institute of Environmental Science \& Research Ltd, PO Box 50 348, Porirua, Wellington 5240, New Zealand. 'Department of Public Health, University of Otago, Wellington, PO Box 7343, Wellington 6242, New Zealand. ${ }^{8}$ Allan Wilson Centre for Molecular Ecology \& Evolution, Palmerston North, New Zealand.

Received: 24 April 2013 Accepted: 26 September 2013 Published: 30 September 2013

\section{References}

1. Griffin PM, Ostroff SM, Tauxe RV, Greene KD, Wells JG, Lewis JH, Blake PA Illnesses associated with Escherichia coli 0157:H7 infections-a broad clinical spectrum. Ann Intern Med 1988, 109(9):705-712.

2. Besser RE, Griffin PM, Slutsker L: Escherichia coli O157:H7 gastroenteritis and the hemolytic uremic syndrome: an emerging infectious disease. Annu Rev Med 1999, 50(1):355-367.

3. Wells JG, Shipman LD, Greene KD, Sowers EG, Green JH, Cameron DN, Downes FP, Martin ML, Griffin PM, Ostroff SM, et al: Isolation of Escherichia coli serotype 0157:H7 and other Shiga-like-toxin-producing E. coli from dairy cattle. J Clin Microbiol 1991, 29(5):985-989.
4. Borczyk AA, Karmali MA, Lior H, Duncan LM: Bovine reservoir for verotoxinproducing Escherichia coli O157:H7. Lancet 1987, 1:98

5. Gelting RJ, Baloch MA, Zarate-Bermudez MA, Selman C: Irrigation water issues potentially related to the 2006 multistate $E$. coli 0157:H7 outbreak associated with spinach. Agr Water Manage 2011, 98(9):1395-1402.

6. Wells JG, Davis BR, Wachsmuth IK, Riley LW, Remis RS, Sokolow R, Morris GK: Laboratory investigation of hemorrhagic colitis outbreaks associated with a rare Escherichia coli serotype. J Clin Microbiol 1983, 18(3):512-520

7. Guh A, Phan Q, Randall N, Purviance K, Milardo E, Kinney S, Mshar P, Kasacek W, Cartter M: Outbreak of Escherichia coli 0157 associated with raw milk, Connecticut, 2008. Clin Infect Dis 2010, 51(12):1411-1417.

8. Werber D, Behnke SC, Fruth A, Merle R, Menzler S, Glaser S, Kreienbrock L, Prager $\mathrm{R}$, Tschape $H$, Roggentin $P$, et al: Shiga toxin-producing Escherichia coli infection in Germany-different risk factors for different age groups. Am J Epidemiol 2007, 165(4):425-434.

9. Bielaszewska M, Janda J, Bláhová K, Minaříková H, Jíkoví E, Karmali MA, Laubová J, Šikulová J, Preston MA, Khakhria R, et al: Human Escherichia coli 0157:H7 infection associated with the consumption of unpasteurized goat's milk. Epidemiol Infect 1997, 119(3):299-305.

10. Deschênes G, Casenave C, Grimont F, Desenclos JC, Benoit S, Collin M, Baron S, Mariani P, Grimont PAD, Nivet H: Cluster of cases of haemolytic uraemic syndrome due to unpasteurised cheese. Pediatr Nephrol 1996, 10(2):203-205.

11. Kassenborg HD, Hedberg CW, Hoekstra M, Evans MC, Chin AE, Marcus R, Vugia DJ, Smith K, Ahuja SD, Slutsker L, et al: Farm visits and undercooked hamburgers as major risk factors for sporadic Escherichia coli 0157:H7 infection: data from a case-control study in 5 FoodNet sites. Clin Infect Dis 2004, 38(Supplement 3):S271-S278.

12. Bell B, Goldoft M, Griffin P, Davis M, Gordon D, Tarr P, Bartleson C, Lewis J, Barrett T, Wells J, et al: A multistate outbreak of Escherichia coli 0157:H7associated bloody diarrhea and hemolytic uremic syndrome from hamburgers. J Amer Med Assoc 1994, 272(17):1349-1353.

13. Riley LW, Remis RS, Helgerson SD, McGee HB, Wells JG, Davis BR, Hebert RJ Olcott ES, Johnson LM, Hargrett NT, et al: Hemorrhagic colitis associated with a rare Escherichia coli serotype. New Engl J Med 1983, 308(12):681-685.

14. Ethelberg S, Smith B, Torpdahl M, Lisby M, Boel J, Jensen T, Møller Nielsen E, Mølbak K: Outbreak of non-0157 Shiga toxin-producing Escherichia coli infection from consumption of beef sausage. Clin Infect Dis 2009, 48(8):e78-e81.

15. Schimmer B, Nygard K, Eriksen H-M, Lassen J, Lindstedt B-A, Brandal LT, Kapperud G, Aavitsland P: Outbreak of haemolytic uraemic syndrome in Norway caused by stx2-positive Escherichia coli 0103:H25 traced to cured mutton sausages. BMC Infect Dis 2008, 8(1):41.

16. Ackers M-L, Mahon BE, Leahy E, Goode B, Damrow T, Hayes PS, Bibb WF, Rice DH, Barrett TJ, Hutwagner L, et al: An outbreak of Escherichia coli 0157:H7 infections associated with leaf lettuce consumption. J Infect Dis 1998, 177(6):1588-1593.

17. Cody SH, Glynn MK: An outbreak of Escherichia coli 0157:H7 infection from unpasteurized commercial apple juice. Ann Intern Med 1999, 130(3):202-209.

18. Marion JW, Lee J, Lemeshow S, Buckley TJ: Association of gastrointestinal illness and recreational water exposure at an inland U.S. beach. Water Res 2010, 44(16):4796-4804.

19. Licence K, Oates KR, Synge BA, Reid TMS: An outbreak of E. coli 0157 infection with evidence of spread from animals to man through contamination of a private water supply. Epidemiol Infect 2001, 126(1):135-138.

20. Keene WE, MCAnulty JM, Hoesly FC, Williams LP Jr, Hedberg K, Oxman GL, Barrett TJ, Pfaller MA, Fleming DW: A swimming-associated outbreak of hemorrhagic colitis caused by Escherichia coli 0157:H7 and Shigella sonnei. New Engl J Med 1994, 331(9):579-584.

21. Rivas M, Sosa-Estani S, Rangel J, Caletti MG, Valles P, Roldan CD, Balbi L, de Mollar MC, Amoedo D, Miliwebsky E, et al: Risk factors for sporadic shiga toxin-producing Escherichia coli infections in children. Argentina. Emerg Infect Dis 2008, 14(5):763-771.

22. Centers for Disease Control and Prevention (CDC): National Shiga toxinproducing Escherichia coli (STEC) Surveillance Annual Summary, 2009. Atlanta, Georgia, USA: US Department of Health and Human Services, CDC; 2012. 
23. European Centre for Disease Prevention and Control: Annual epidemiological report 2012. Reporting on 2010 surveillance data and 2011 epidemic intelligence data. Stockholm, Sweden: ECDC; 2013:245.

24. Wright J, Fraser D, Baker M: Escherichia coli 0157:H7 infection: first New Zealand case report. Communicable Disease New Zealand 1993, 93(9):113-116.

25. Institute of Environmental Science and Research Ltd: Surveillance reportnotifiable and other diseases in New Zealand: annual report 2012. Porirua, New Zealand; 2013:101.

26. Centers for Disease Control and Prevention (CDC) USA: Epi Info, version 6.04b. 2001

27. Shringi S, Schmidt C, Katherine K, Brayton KA, Hancock DD, Besser TE: Carriage of stx2a differentiates clinical and bovine-biased strains of Escherichia coli 0157. PLoS One 2012, 7(12):e51572.

28. Besser TE, Shaikh N, Holt NJ, Tarr PI, Konkel ME, Malik-Kale P, Walsh CW, Whittam TS, Bono JL: Greater diversity of Shiga toxin-encoding bacteriophage insertion sites among Escherichia coli 0157:H7 isolates from cattle than in those from humans. Appl Environ Microb 2007, 73(3):671-679

29. R Core Team: $R$ : a language and environment for statistical computing 2.15 .2 edn. Vienna, Austria: R Foundation for Statistical Computing; 2012.

30. Lewin-Koh NJ, Bivand R: Package 'maptools': tools for reading and handling spatial objects. 2013.

31. Baddeley A, Turner R: Spatstat: an R package for analyzing spatial point patterns. J Stat Softw 2005, 12(6):1-42.

32. Davies TM, Hazelton ML, Marshall JC: Sparr: analyzing spatial relative risk using fixed and adaptive kernel density estimation in R. J Stat Softw 2011, 39(1):1-14.

33. Statistics New Zealand: Infoshare. Wellington, New Zealand: Statistics New Zealand. Retrieved from http://www.stats.govt.nz/infoshare/ on 17 Aug 2013.

34. AsureQuality: AgriBase ${ }^{\mathrm{TM}}$. Auckland, New Zealand.

35. Scheffer J: Dealing with missing data. Res Lett Inf Math Sci 2002, 3:153-160.

36. van Buuren S: mice: multivariate imputation by chained equations (R package) 2.13 edn. 2012

37. Hosmer DW, Lemeshow S: Applied logistic regression. 2nd edition. New York: John Wiley \& Sons, Inc; 2000.

38. Harrell FE Jr: rms: regression modeling strategies (R package) 3.6-3 edn. ; 2013.

39. Stafford RJ, Schluter PJ, Wilson AJ, Kirk MD, Hall G, Unicomb L, OzFoodNet Working Group: Population-attributable risk estimates for risk factors associated with Campylobacter infection, Australia. Emerg Infect Dis 2008, 14(6):895-901

40. Rockhill B, Newman B, Weinberg C: Use and misuse of population attributable fractions. Am J Public Health 1998, 88(1):15-19.

41. Applied Maths NV: BioNumerics ${ }^{\oplus} 6.6$ edn. Sint-Martens-Latem, Belgium: The universal platform for databasing and analysis of all biological data.

42. Clarke KR, Gorley RN: PRIMER v6: user manual/tutorial. Plymouth, United Kingdom: PRIMER-E Ltd.; 2006.

43. Statistics New Zealand: New Zealand Official Yearbook 2010. New Zealand: Auckland; 2010:536.

44. Institute of Environmental Science and Research Ltd: Notifiable and other diseases in New Zealand: annual report 2010. Porirua, New Zealand; 2011:103.

45. Institute of Environmental Science and Research Ltd: Notifiable and other diseases in New Zealand: annual report 2009. Porirua, New Zealand; 2010:64.

46. Institute of Environmental Science and Research Ltd: Notifiable and other diseases in New Zealand: annual report 2008. Porirua, New Zealand; 2009:59.

47. Institute of Environmental Science and Research Ltd: Notifiable and other diseases in New Zealand: annual report 2011. Porirua, New Zealand; 2012:101.

48. Friesema IHM, Van de Kassteele J, De Jager CM, Heuvelink AE, Van Pelt W: Geographical association between livestock density and human Shiga toxin-producing Escherichia coli 0157 infections. Epidemiol Infect 2011, 139(7):1081-1087.

49. Milnes AS, Sayers AR, Stewart I, Clifton-Hadley FA, Davies RH, Newell DG, Cook AJC, Evans SJ, Smith RP, Paiba GA: Factors related to the carriage of Verocytotoxigenic E. coli, Salmonella, thermophilic Campylobacter and Yersinia enterocolitica in cattle, sheep and pigs at slaughter. Epidemiol Infect 2009, 137(08):1135-1148.

50. Jaros P, Cookson AL, Prattley DJ, Campbell DM, Hathaway S, French NP: Shedding of Escherichia coli 0157:H7 and O26 STEC by slaughter cattle in New Zealand. In Annual meeting of the New Zealand Microbiological Society (NZMS). 23-25 November 2011; Palmerston North, New Zealand. 2011:86.
51. Lal A, Hales S, French N, Baker MG: Seasonality in human zoonotic enteric diseases: a systematic review. PLOS ONE 2012, 7(4):e31883.

52. Baker M, Williman J: The epidemiology of VTEC in New Zealand: what it tells us about this disease. In Proceedings of the Food Safety, Animal Welfare \& Biosecurity, Epidemiology \& Animal Health Management, and Industry branches of the NZVA. vol. FCE Publication No. 276. 24-27 June 2009. Rotorua, New Zealand: VetLearn Foundation; 2009:29-38.

53. Jalava K, Ollgren J, Eklund M, Siitonen A, Kuusi M: Agricultural, socioeconomic and environmental variables as risks for human verotoxigenic Escherichia coli (VTEC) infection in Finland. BMC Infect Dis 2011, 11:275.

54. Innocent GT, Mellor DJ, McEwen SA, Reilly WJ, Smallwood J, Locking ME, Shaw DJ, Michel P, Taylor DJ, Steele WB, et al: Spatial and temporal epidemiology of sporadic human cases of Escherichia coli 0157 in Scotland 1996-1999. Epidemiol Infect 2005, 153(6):1033-1041.

55. Kistemann T, Zimmer S, Vagsholm I, Andersson Y: GIS-supported investigation of human EHEC and cattle VTEC 0157 infections in Sweden: geographical distribution, spatial variation and possible risk factors. Epidemiol Infect 2004, 132(3):495-505.

56. Valcour JE, Michel P, McEwen SA, Wilson JB: Associations between indicators of livestock farming intensity and incidence of human Shiga toxin-producing Escherichia coli infection. Emerg Infect Dis 2002, 8(3):252-257.

57. Michel P, Wilson JB, Martin SW, Clarke RC, McEwen SA, Gyles CL: Temporal and geographic distributions of reported cases of Escherichia coli 0157: H7 infection in Ontario. Epidemiol Infect 1999, 122(2):193-200.

58. Wong TL: Potential dissemination of Campylobacter by farmers' overalls in broiler farms. In Report FW09004. New Zealand: Institute of Environmental Science and Research Ltd; 2009.

59. Baker MG, Thornley CN, Lopez LD, Garrett NK, Nicol CM: A recurring salmonellosis epidemic in New Zealand linked to contact with sheep. Epidemiol Infect 2007, 135(01):76-83.

60. Beamer P, Key ME, Ferguson AC, Canales RA, Auyeung W, James O: Quantified activity pattern data from 6 to 27-month-old farmworker children for use in exposure assessment. Environ Res 2008, 108(2):239-246.

61. Reed KJ, Jimenez M, Freeman NCG, Lioy PJ: Quantification of children's hand and mouthing activities through a videotaping methodology. J Expo Anal Env Epid 1999, 9(5):513-520.

62. Thorburn D: Ruminant density, verocytotoxigenic Escherichia coli and cryptosporidiosis in New Zealand: descriptive and ecological analyses. Dissertation: University of Otago, Dunedin, New Zealand; 2010.

63. O'Brien SJ, Adak GK, Gilham C: Contact with farming environment as a major risk factor for Shiga toxin (verocytotoxin)-producing Escherichia coli O157 infection in humans. Emerg Infect Dis 2001, 7(6):1049-1051.

64. Locking ME, O'Brien SJ, Reilly WJ, Campbell DM, Browning LM, Wright EM, Coia JE, Ramsay JE: Risk factors for sporadic cases of Escherichia coli 0157 infection: the importance of contact with animal excreta. Epidemiol Infect 2001, 127(2):215-220.

65. Voetsch AC, Kennedy MH, Keene WE, Smith KE, Rebatsky-Ehr T, Zansky S, Thomas SM, Mohle-Boetani J, Sparlings PH, McGavern MB, et al: Risk factors for sporadic Shiga toxin-producing Escherichia coli 0157 infections in FoodNet sites, 1999-2000. Epidemiol Infect 2007, 135(6):993-1000.

66. Paunio M, Pebody R, Keskimaki M, Kokki M, Ruutu P, Oinonen S, Vuotari V, Siitonen A, Lahti E, Leinikki P: Swimming-associated outbreak of Escherichia coli 0157:H7. Epidemiol Infect 1999, 122(1):1-5.

67. Denno DM, Keene WE, Hutter CM, Koepsell JK, Patnode M, Flodin-Hursh D, Stewart LK, Duchin JS, Rasmussen L, Jones R, et al: Tri-county comprehensive assessment of risk factors for sporadic reportable bacterial enteric infection in children. J Infect Dis 2009, 199(4):467-476.

68. Lake R, Horn B, Ball A: Campylobacter in food and the environment examining the link with public health: pathway attribution (part II). In Report FW10007 Part II. Christchurch, New Zealand: Institute of Environmental Science and Research Ltd; 2010:89.

69. McPherson M, Lalor K, Combs B, Raupach J, Stafford R, Kirk MD: Serogroupspecific risk factors for Shiga toxin-producing Escherichia coli infection in Australia. Clin Infect Dis 2009, 49(2):249-256.

70. Nohynek LJ, Alakomi H-L, Kähkönen MP, Heinonen M, Helander IM, Oksman-Caldentey K-M, Puupponen-Pimi RH: Berry phenolics: antimicrobial properties and mechanisms of action against severe human pathogens. Nutr Cancer 2006, 54(1):18-32. 
71. Islam S: Sweetpotato (Ipomoea batatas L.) leaf: its potential effect on human health and nutrition. J Food Sci 2006, 71(2):R13-R21.

72. Jaros P, Cookson AL, Prattley DJ, Besser TE, Jung WK, Campbell DM, Hathaway S, French NP: Molecular epidemiology: a tool for source attribution investigation of Escherichia coli 0157:H7 infections in New Zealand. In 13th International Symposium on Veterinary Epidemiology and Economics (ISVEE). 20-24 August 2012; Maastricht, The Netherlands. 2012:540.

73. Whitworth JH, Fegan N, Keller J, Gobius KS, Bono JL, Call DR, Hancock DD, Besser TE: International comparison of clinical, bovine, and environmental Escherichia coli $\mathrm{O} 157$ isolates on the basis of Shiga toxinencoding bacteriophage insertion site genotypes. Appl Environ Microb 2008, 74(23):7447-7450

74. Shringi S, García A, Lahmers KK, Potter KA, Muthupalani S, Swennes AG, Hovde CJ, Call DR, Fox JG, Besser TE: Differential virulence of clinical and bovine-biased enterohemorrhagic E. coli 0157:H7 genotypes in piglet and Dutch Belted rabbit models. Infect Immun 2012, 80(1):369-380.

75. Fuller CA, Pellino CA, Flagler MJ, Strasser JE, Weiss AA: Shiga toxin subtypes display dramatic differences in potency. Infect Immun 2011, 79(3):1329-1337.

76. Dohoo I, Martin W, Stryhn H: Validity in observational studies. In Veterinary epidemiologic research. 2nd edition. Edited by McPike SM. Charlottetown, Prince Edward Island, Canada: VER Inc; 2010:243-270.

77. Scallan E, Hoekstra RM, Angulo FJ, Tauxe RV, Widdowson M-A, Roy SL, Jones $J$, Griffin PM: Foodborne illness acquired in the United States-major pathogens. Emerg Infect Dis 2011, 17(1):7-15.

78. Tam CC, Rodrigues LC, Viviani L, Dodds JP, Evans MR, Hunter PR, Gray رل Letley $L H$, Rait G, Tompkins DS, et al: Longitudinal study of infectious intestinal disease in the UK (IID2 study): incidence in the community and presenting to general practice. Gut 2012, 61(1):69-77.

doi:10.1186/1471-2334-13-450

Cite this article as: Jaros et al:: A prospective case-control and molecular epidemiological study of human cases of Shiga toxinproducing Escherichia coli in New Zealand. BMC Infectious Diseases 2013 13:450.

\section{Submit your next manuscript to BioMed Central and take full advantage of:}

- Convenient online submission

- Thorough peer review

- No space constraints or color figure charges

- Immediate publication on acceptance

- Inclusion in PubMed, CAS, Scopus and Google Scholar

- Research which is freely available for redistribution 